
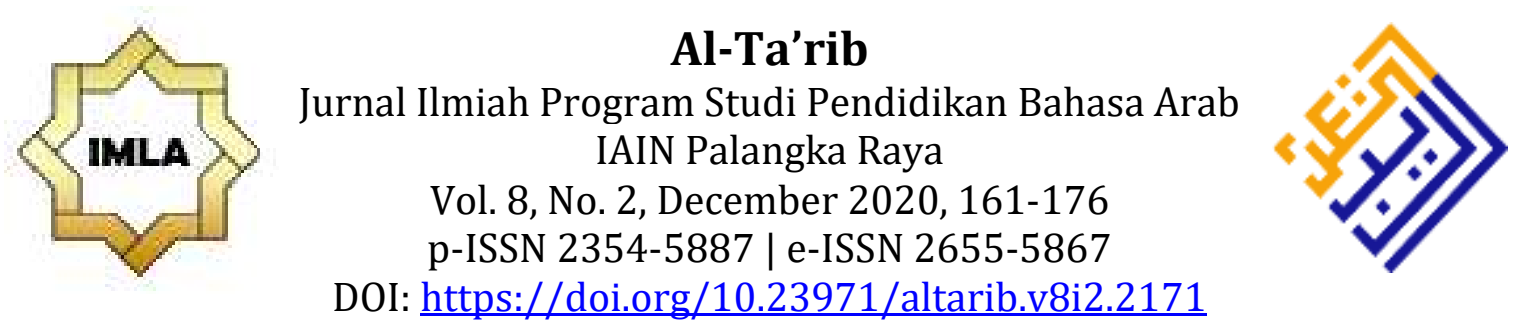

\title{
TIPOLOGI KONSTRUKSI MAKNA KATA “TALIBAN” PADA KOMISI PEMBERANTASAN KORUPSI (KPK)
}

\author{
M. Azizzullah Ilyas \\ Institut Agama Islam Negeri Bengkulu, Indonesia \\ E-mail: alcurufi@gmail.com
}

\begin{abstract}
The word Taliban has been used by the public and is widely known as the name of the faction of the armed political movement in Afghanistan. However, in the past some time, the term Taliban is often used as a name for a group within the Corruption Eradication Commission (KPK). This raises different meanings and different perceptions. This study aims to analyze how the word Taliban is understood and used in the KPK, how the shape shifts in meaning, and how the construction process patterns. This study uses a descriptive-qualitative approach with data taken from literature and it is enriched with interview and questionnaire data. This study found that the development of meaning was unpredictable but found conclusions in synchronic phenomena when there was a large and open use of words. The common conception and common understanding on the word "Taliban" is doubtful because it can be broadly constructed. The semantic fields used are nouns and adjectives with various meanings. Meaning is constructed from individual perspectives, social and cultural contexts, the it is continued to mutual understanding and natural agreement. Peryoration and amelioration types were the most noticeable patterns of change. However, the positive-positive meaning is also a different pattern found in shifting the meaning of the Taliban in the KPK.
\end{abstract}

Keywords: Meaning Construction; Taliban; KPK

\begin{abstract}
Abstrak
Kata Taliban selama ini digunakan oleh masyarakat dan dikenal luas sebagai nama faksi gerakan politik bersenjata di Afganistan. Namun, pada beberapa waktu yang lalu istilah Taliban sering digunakan sebagai penamaan terhadap kelompok yang terdapat di dalam tubuh Komisi Pemberantasan Korupsi (KPK). Hal ini memunculkan pemaknaan yang beragam dan persepsi yang berbeda-beda. Penelitian ini bertujuan menganalisis bagaimana kata Taliban dipahami dan digunakan di KPK, bagaimana bentuk pergeseran makna, serta bagaimana pola proses konstruksi. Kajian ini menggunakan pendekatan deskriptif-kualitatif dengan data yang bersumber dari kepustakaan serta diperkaya dengan data wawancara dan angket. Penelitian ini menemukan bahwa perkembangan makna tidak dapat diprediksi namun menemukan kesimpulan dalam fenomena sinkronik ketika terjadi
\end{abstract}


penggunaan kata secara massal dan terbuka. Pada kata "Taliban" konsepsi umum dan pemahaman bersama diragukan dapat terkonstruksi secara luas. medan semantik yang digunakan berbentuk nomina dan adjektiva dengan makna beragam. Makna terkontruksi dalam wawasan, konteks sosial dan budaya individu yang berlanjut pada pemahaman dan kesepakatan alamiah bersama. Tipe peyorasi dan ameliorasi merupakan pola perubahan yang paling ketara. namun, pemaknaan positif-positif juga merupakan pola berbeda yang ditemukan dalam pergeseran makna Taliban di KPK.

Kata Kunci: konstruksi makna; Taliban; KPK

\section{Pendahuluan}

Terdapat banyak kata asing yang diserap dan digunakan dalam bahasa Indonesia, baik yang berasal dari bahasa-bahasa yang serumpun internal Nusantara ataupun bahasa-bahasa asing. Bahasa serapan banyak dijumpai dengan mudah baik dalam komunikasi di masyarakat ataupun di dalam kamus-kamus berbahasa Indonesia. Bahasa-bahasa pendonor tersebut meliputi bahasa pendonor besar seperti bahasa Arab dan Inggris, bahasa pendonor menengah seperti bahasa Persia, India, Belanda ataupun dari bahasa pendonor kecil seperti bahasa Cina, Bangladesh dan Afganistan.

Bahasa Indonesia sebagai bahasa terbuka untuk berkembang menerima banyak kosakata asing baik yang berlanjut pada proses integrasi dan penyesuaian bunyi ataupun yang hanya berhenti pada penggunaan sementara tanpa adanya penyerapan dan integrasi.

Beberapa waktu lalu wacana publik diramaikan dengan penggunaan istilah Taliban dalam narasi-narasi yang berkaitan dengan kelompok atau orang-orang tertentu yang terdapat di dalam organ Komisi Pemberantasan Korupsi (KPK). Istilah "Taliban" tersebut menjadi pembicaraan di masyarakat, di media elektronik maupun media online. Seperti judul headline dalam situs www.gusdurian.net 11 September 2019 "Taliban, Oh Taliban. Kamu Ngapain Sih di KPK?" (Kampung Gusdurian, n.d.). Judul opini di www.tagar.id “Deny Siregar: Irjen Firli, Momok Bagi Taliban di KPK" (News, 2017).

Perbincangan publik terhadap istilah "Taliban" memunculkan persepsi yang beragam. kata tersebut memunculkan makna pada situasi dan latar psikologi berdasarkan wawasan individu, jender, strata sosial, tingkat pendidikan dan ketersampaian mengelola Informasi. Perdebatan dan diskusi yang bebas dalam mengembangkan makna Taliban pada konteks KPK muncul dari warung kaki lima hingga kafe-kafe di kampus dan memunculkan makna-makna liar yang mulai eksis di masyarakat. Istilah Taliban yang beberapa tahun ini hilang bersama semakin tersudutnya kelompok ini di wilayah asalnya tiba-tiba muncul kembali dan menjadi kata dengan makna beragam di masyarakat. 
Masyarakat sebagai pengguna bahasa dalam banyak kasus memiliki kreativitas yang bebas dan kewenangan yang sempurna dalam memproduksi, mengimpor dan memberikan makna terhadap kosa-kata baru secara alamiah tanpa dipengaruhi oleh lembaga tertentu yang diberikan kewenangan oleh pemerintah untuk mengatur perkembangan bahasa. Pada penggunaanya di masyarakat kosa-kata tersebut memunculkan makna-makna baru yang berbeda dari makna asli, bergantung pemakaian bahasa dan faktor sosial situasional. Sosiolinguistik melihat bahasa sebagai sistem sosial dan sistem komunikasi, serta merupakan bagian dari kebudayaan dari masyarakat tertentu. Bahasa merupakan bentuk interaksi sosial yang terjadi di masyarakat dalam situasi yang kongkret.

Kata yang telah digunakan sebelumnya dengan makna tertentu dapat mengalami perubahan. perubahan-perubahan tersebut telah diklasifikasikan secara tradisional. Salah satu tipologi tradisional perubahan makna dikenal dengan istilah ameliorasi, yakni situasi di mana kata yang semula memiliki makna negatif atau berdenotasi buruk berkembang atau mengalami pergeseran menjadi bermakna positif, ataupun sebaliknya mengalami peyorasi dimana kata yang bermakna positif menjadi negatif (Wijana \& Rohmadi, 2008).

Tipologi lain yaitu perubahan makna yang meluas atau menyempit, metafora; dimana makna mengalami perubahan disebabkan adanya sedikit kesamaan antara dua konsep kata atau metonimi dimana konsep kata digunakan untuk mengacu kepada sesuatu yang tidak memiliki kesamaan, melainkan disebabkana adanya sedikit hubungan saja.

Pergeseran, dan perluasan makna dapat disebabkan oleh perkembangan ilmu dan teknologi, faktor sosial budaya, perbedaan bidang pemakaian, adanya asosiasi pertukaran tanggapan indera, dan adanya hubungan antara bentuk ujaran dengan sesuatu yang lain yang berkenaan dengan bentuk ujaran itu, sehingga apabila disebut ujaran tertentu, yang dimaksud adalah sesuatu yang lain yang berkenaan dengan ujaran tersebut (Chaer, 1990). Bloomfield berpendapat bahwa perubahan makna dapat berbentuk penyempitan, pelebaran, hiperbola dan metafora. Setiap perubahan semantik kata akan mempengaruhi kata-kata lain secara bidang leksikal (Bloomfield, L, 1933). Selain itu perubahan makna dapat juga disebabkan oleh faktor budaya, perkembangan teknologi dan faktor linguistik seperti subjektifitas (Hamilton et al., 2016). Perubahan-perubahan makna terjadi setiap waktu dalam banyak kata dan menjadi hal yang lumrah untuk akhirnya kata menemukan makna tertentu yang digunakan dalam konteks tertentu.

Sebuah kata memiliki struktur makna yang sangat kompleks. Sebuah kata dibangun melalui komponen-komponen makna yang lebih kecil yang digabungkan secara berbeda untuk membentuk yang suatu kata baru yang utuh yang memiliki unsur-unsur makna yang berkaitan (Crystal, 1997). Dan Makna sangat berkaitan dengan kemampuan memahami dan kemampuan berpikir logis manusia. ketika 
kita menganalisis makna, sesungguhnya kita tengah menganalisis kemampuan kita sendiri dalam berpikir dan memahami dan menciptakan makna (Leech, 1981).

Untuk menelaah makna suatu kata dapat dilakukan analisis komponen makna, dimana analisa tersebut didasarkan pada anggapan bahwa makna kata terdiri dari komponen semantik. Jadi fitur penting yang membentuk makna adalah satuan pada tingkat dasar semantik. Dengan analisis komponen, satuan terkecil yang tidak didefinisikan dan tidak terpisah dari kata dapat ditemukan (Aitchison, 2003). Terdapat empat prosedur dalam menganalisa komponen makna secara akurat, yaitu; penamaan, parafrase, pendefinisian, dan klasifikasi (Nida, 1975).

Trier berpandangan bahwa medan makna berhubungan secara paradigmatik, yang berkaitan dengan hubungan paradigmatik antar kata baik secara hiponimi, sinonim dan antonim. Medan makna digunakan untuk melihat properti pada suatu kata. Medan makna menunjukkan realitas yang dikandung oleh kata tertentu (Brinton, n.d.). Sebuah kata memiliki makna sempurna ketika ia berada dalam medan maknanya secara konsep, dan akan mengalami pengurangan atau penambahan makna saat berada dalam konteks.

Terdapat beberapa kajian terdahulu mengenai pergeseran makna diantaranya; Pergeseran Makna: Analisis Peyorasi Dan Ameliorasi Dalam Konteks Kalimat yang ditulis oleh Fika Rahma, yang mengkaji sisi ameliorasi dan peyorasi. Pada kesimpulan disebutkan bahwa bahasa yang makin hari semakin berkembang. Peyorasi dan ameliorasi dapat menjadikan suatu perubahan ataupun pergeseran makna, dan penggunaan atau pemilihan kata baik peyorasi atau pun ameliorasi bergantung pada fungsi dan tujuan pemakaiannya (Rahma, 2018).

Kajian lain berjudul; Analisis Perubahan Makna Pada Bahasa Yang Digunakan Oleh Komentator Sepak Bola Piala Presiden 2017, yang menemukan bahwa makna dalam kajian tersebut mengalami proses perluasan, penyempitan, penghalusan dan mengkasaran. Menurut kajian tersebut perubahan makna bertujuan untuk menarik minat dan menumbuhkan semangat penonton (Sempana et al., 2017). Wiwitan juga melakukan kajian mengenai konstruksi makna "publik relasi marketing". Kajian ini menggunakan teori Berger untuk mengkonstruksi makna sosial (Wiwitan \& Yulianita, 2018).

Anne E Kane, menganalisa konstruksi makna pada gerakan sosial di Irlandia, yang menggunakan pendekatan Sosilogi, semiotik dan hermeneutika untuk menjelaskan bagaimana makna dibangun dan sistem budaya bertransformasi bersamaan dengan kejadian sejarah (Kane, 2016). Selain itu Anuradha juga menulis tentang konstruksi makna "work" pada masyarakat pekerja di India. Kajian ini berusaha menemukan makna dominan dari "work" yang di pahami oleh masyarakat. Kajian ini menemukan bahwa kata "work" memiliki makna ganda pada satu individu, makna dalam tataran sosial dan makna dalam tataran personal (Anuradha et al., 2014). 
Untuk memberikan penjelasan mengenai pola pergeseran makna tersebut penelitian ini menampilkan analisa lewat pendekatan semantik-sosiolinguistik singkronik untuk menggambarkan pola pemaknaan terhadap kata Taliban. Untuk lebih spesifik penelitian ini mencoba mengkaji bagaimana medan semantik kata Taliban yang digunakan oleh pegawai KPK?, bagaimana pola proses konstruksi makna?, serta bagaimana tipologi perubahan makna?.

\section{Metode}

Data dikumpulkan menggunakan metode kuesioner terbuka dan tertutup dengan sampel acak. kuesioner terbuka dipilih untuk memberikan kesempatan seluas-luasnya kepada responden untuk memberikan jawaban atau tanggapannya sehingga data yang ingin dikumpulkan dapat lebih objektif. Responden terdiri dari 25 pegawai Komisi Pemberantasan Korupsi (KPK) yang dipilih secara acak. Respon dibutuhkan untuk menelaah pola pergeseran makna kata dan untuk memahami unsur sosial situasional yang mempengaruhi perubahan makna tersebut. Dipilihnya pegawai KPK sebagai responden untuk lebih mempertegas makna apa yang diinginkan oleh penutur dan mempersempit lingkup kajian. Selain itu, untuk mendekatkan makna pada konteks dan variabel sosiolinguistik. dilakukan juga wawancara langsung dengan dua orang perwakilan pegawai KPK.

\section{Hasil Penelitian dan Pembahasan}

Untuk mengetahui properti yang dimiliki oleh suatu kata, dapat dilakukan analisis medan makna. Melalui analisis medan makna tersebut akan dapat diamati bentuk pergeseran realitas makna yang terjadi secara sinkronik. Pergeseran makna dapat diukur dengan membandingkan medan makna yang dibangun lebih awal yang dipengaruhi oleh proses semantik standar dan pergeseran makna yang disebabkan oleh faktor budaya dan atau kontek interaksi sosial tertentu. Pada kasus kata Taliban analisa terhadap perbandingan medan makna dilakukan dengan membandingkan antara medan makna leksikal dan medan makna kultural.

Kata Taliban sendiri merupakan kata yang telah mengalami beberapa kali proses fonologis lintas bahasa, kata ini secara original berasal dari bahasa Arab "طالب (Thalibun) yang bermakna pelajar atau siswa, yang kemudian diserap kedalam bahasa Persia dengan mengalami penambahan bunyi "An", dan berlanjut diserap kedalam bahasa Pashto, salah satu bahasa suku di Afghanistan. Secara leksikal dalam referensi klasik kata "Thalibun" belum memiliki makna seperti saat ini, dalam Mu'jam a'in ataupun Maqhayis Lughah belum terdapat kata "طالب yang dituliskan secara khusus. 


\section{Diagram 1.}

\section{Penyempitan makna leksikal kata “Thalibun" dari bahasa Arab ke bahasa Persia}

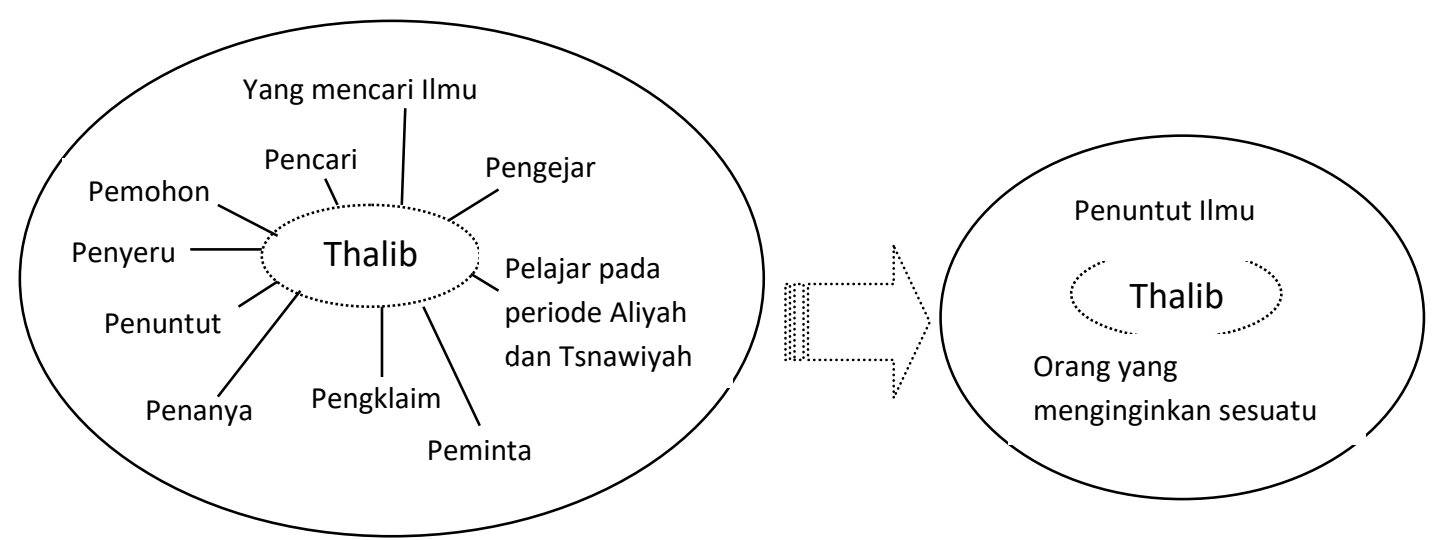

Kata Thalib selanjutnya diserap kedalam bahasa Persia tanpa ada perubahan bunyi, namun makna kata tersebut mengalami penyempitan, yang pada awalnya bermakna pencari, pemohon, pelajar tsanawiyah dan aliyah, penuntut ilmu, penanya, penyeru, peminta, pengklaim (Baalbaki, 1998), menjadi penuntut ilmu dan orang yang menginginkan sesuatu (Naim, 1982).

Kata "Thalib" kemudian kembali diserap kedalam bahasa Pashto yang merupakan bahasa etnis Pastun di Afghanistan. Bahasa Pashto menjadi salah satu bahasa resmi di Afghanistan. "Talib" bermakna orang yang mencari, orang yang meminta, pecinta, pelajar. Kata Thalib diserap kemudian mendapatkan akhiran "an" menunjukkan plural dalam bahasa Pashto. Mendapatkan akhiran "an" Taliban bermakna siswa-siswa (Raverty, 2001).

Diagram 2.

\section{Perluasan makna leksikal kata "Thalib" dari bahasa Persia ke bahasa Pastho}

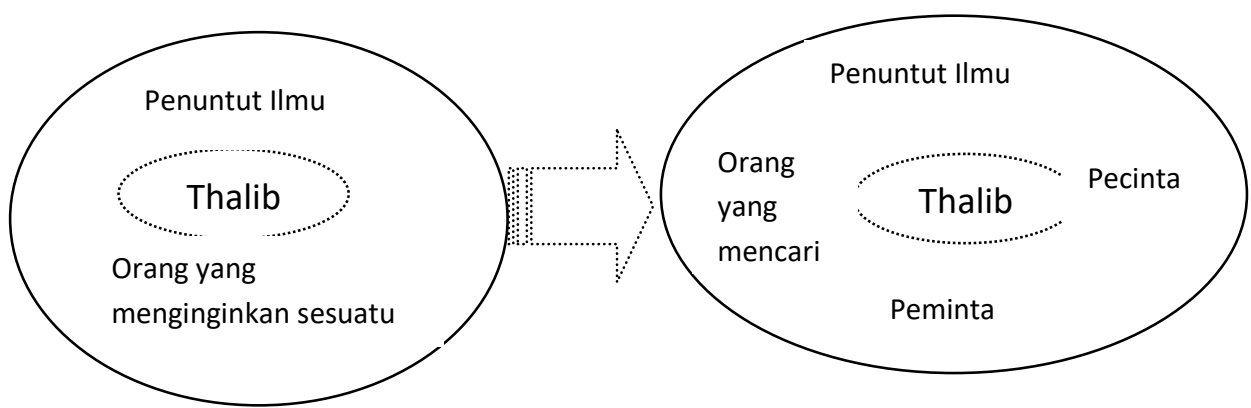

Sedangkan dalam penggunaannya di Indonesia, kata "Taliban" lebih dikenal sebagai gerakan politik bersenjata di Afghanistan. Namun kata "Taliban" kembali digunakan namun dengan makna yang berbeda di KPK. Dari respon yang kami 
peroleh dari 25 sampel, dengan pertanyaan "Apabila dalam ruang lingkup KPK kata "Taliban" memiliki makna berbeda, apakah makna kata Taliban menurut anda?." Terdapat berapa makna kata "Taliban" yang berkembang sebagai berikut;

Tabel 1.

Makna kata Taliban

\begin{tabular}{|c|c|}
\hline Respon & Makna Kata \\
\hline 1 & $\begin{array}{l}\text { Orang yang cenderung bersikap negatif bila berhubungan dengan } \\
\text { instansi tertentu }\end{array}$ \\
\hline 2 & Mereka yang tidak kompromi dengan koruptor, plus relijius \\
\hline 3 & Taliban identik dengan pemberontak \\
\hline 4 & $\begin{array}{l}\text { Taliban di KPK lebih ke kelompok orang yang mempunyai paham } \\
\text { berbeda dan merasa lebih benar daripada yang lainnya.. }\end{array}$ \\
\hline 5 & Teguh pada prinsip, konsisten dalam perbuatan \\
\hline 6 & $\begin{array}{l}\text { Semangat "militan" yang dalam konteks pekerjaan sebagai kiasan } \\
\text { untuk orang terlalu bersemangat dalam bekerja }\end{array}$ \\
\hline 7 & $\begin{array}{l}\text { Kelompok yang memanfaatkan nama besar dan Marwah KPK } \\
\text { untuk }\end{array}$ \\
\hline & kepentingan pribadi dan kelompoknya \\
\hline 8 & Pejuang \\
\hline 9 & $\begin{array}{l}\text { Label yang digunakan oknum luar KPK untuk pegawai KPK yang } \\
\text { dianggap ekstrem dalam hal penampilan (jenggot dan cingkrang) } \\
\text { dan dituduh pro terhadap oposisi }\end{array}$ \\
\hline 10 & Semangat pantang menyerah \\
\hline 11 & Gerakan radikal anti pemerintah \\
\hline 12 & $\begin{array}{l}\text { Kelompok yang berlaku ekstrim (kebanyakan menentang) } \\
\text { terhadap kebijakan pemerintah dan menganggap pemerintah } \\
\text { lawan dari KPK akibat dari afiliasi politik atau simpati politik yang } \\
\text { bersangkutan. }\end{array}$ \\
\hline 13 & $\begin{array}{l}\text { Keras, tidak mempertimbangkan baik dan buruk akibat perbuatan } \\
\text { yang dilakukan }\end{array}$ \\
\hline 14 & Murid yang memiliki keinginan belajar \\
\hline 15 & Golongan eksklusif yang mempunyai cara pandang sendiri \\
\hline
\end{tabular}

Makna-makna yang berkembang dalam suatu komunitas bahasa masih dipengaruhi oleh makna awal kata asing yang dipahami oleh penutur, makna primer dan wawasan penuturpun akan sangat berpengaruh dalam kemampuannya menyimpulkan makna kata.

Berdasarkan data yang di peroleh, dengan menganalisa makna kata "Taliban" yang berkembang pada kompunitas Karyawan Komisi Pemberantasan 
Korupsi, maka dapat dikelompokkan medan makna yang berkembang sebagai berikut;

\section{Diagram 3.}

Medan makna leksikal kata “Taliban” berdasarkan kelas kata.

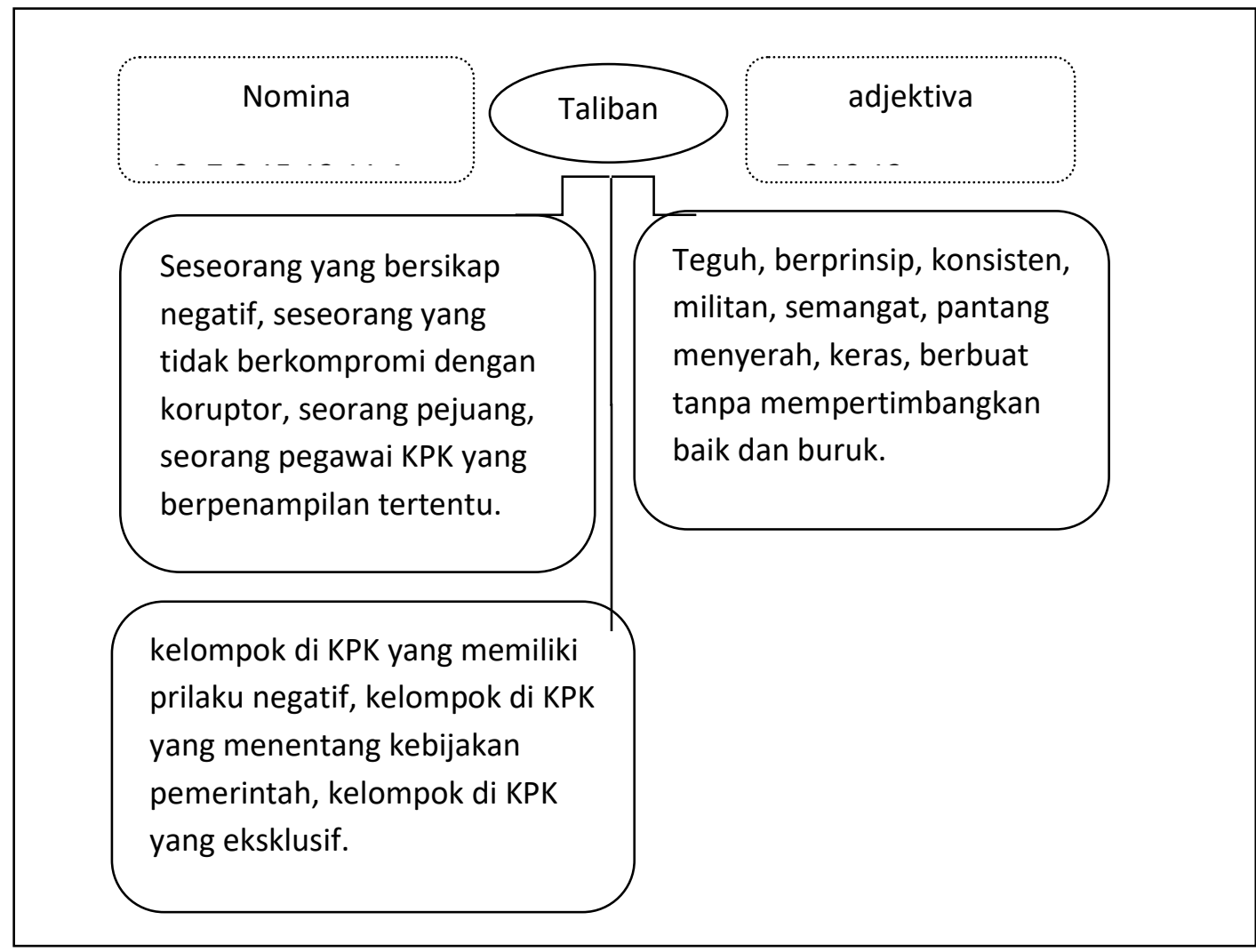

Masyarakat tutur memiliki peranan dalam membentuk makna suatu kata, dalam kasus kata Taliban masyarakat tutur yang berada dalam komunitas memiliki keluasan dan kebebasan untuk menentukan makna kata, hingga makna kata yang digunakan oleh komunitas KPK berkembang tanpa adanya kesepakatan, serta memunculkan makna-makna baru yang beragam. Perbedaan makna tersebut menimbulkan makna yang beragam pula di minda masyarakat umum ketika tibatiba istilah KPK mencuat ke publik.

Selanjutnya makna kata Taliban meluas menjadi makna yang dipahami oleh komunitas tutur KPK dan makna yang dipahami oleh masyarakat umum. Sharing makna Taliban tersebut dapat divisualkan sebagai berikut; 


\section{Diagram 4. \\ Proses pemaknaan komunitas tutur KPK dan proses pemaknaan masyarakat tutur}

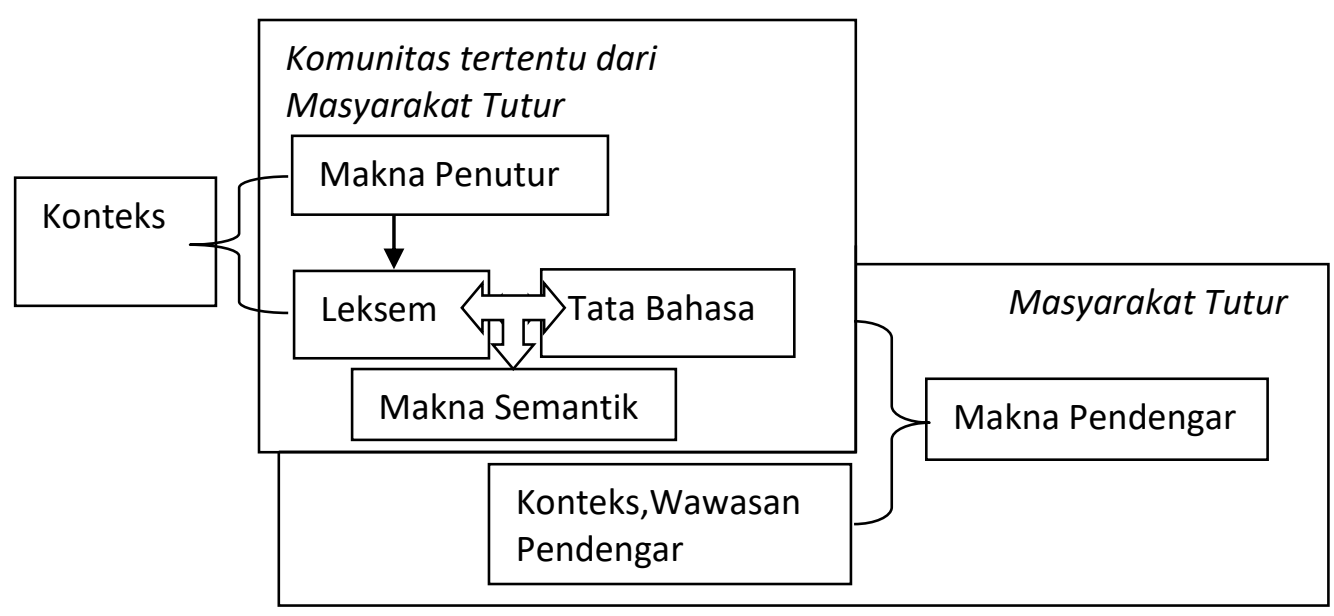

Tidak diketahui secara pasti kapan pertama kali kata Taliban digunakan. Wawancara dengan beberapa informan diketahui bahwa istilah Taliban digunakan untuk penyidik dilatarbelakangi oleh semangat militansi pejuang Taliban yang tinggi, pantang menyerah, bahkan dengan persenjataan seadanya. Konteks Afganistan berganti dengan konteks Indonesia. Indonesia merupakan konteks nonlinguistik atau kultural konteks, dimana memaknai kata berdasarkan situasi dimana kata tersebut digunakan, seperti kata "برحمك الله" yang dapat digunakan untuk orang yang bersin dan dapat juga digunakan untuk orang yang meninggal (Jasim, 2007). Makna kata Taliban di KPK digunakan untuk penyidik yang memiliki militansi dan semangat tinggi dalam pemberantasan korupsi. dan kata Taliban di KPK tidak dimaknai sebagai sayap faksi gerakan politik bersenjata Afganistan di Indonesia yang anti terhadap pemerintah.

\section{Tipologi Makna}

Bila diamati makna kata Taliban mengalami perkembangan yang dapat diklasifikasin menjadi beberapa tipe diantaranya; tipologi peyorasi dan ameliorasi. Peyorasi ataupun ameliorasi akan sangat bergantung kepada pandangan awal penutur mengenai kata asing tersebut. Penutur memiliki kebebasan untuk memberikan makna pada kata, baik makna tersebut positif atau negatif.

Pada responden $2,5,8,10,14$ dapat dikategorikan sebagai ameliorasi apabila responden menganggap makna awal kata Taliban adalah faksi politik bersenjata di Afganistan sebagai kata yang bermakna negatif. Namun bentuk lain muncul yakni apabila kata Taliban pada awalnya dianggap bermakna positif dan mengalami pergeseran menjadi kata yang bermakna positif pula.

Demikian pula dengan responden $1,3,4,6,7,9,11,12,13,15$. Para responden dapat memahami pergeseran makna kata Taliban berpola peyorasi, 
apabila persepsi responden terhadap kata "Taliban" positif. Namun sebagaimana pada responden $2,5,8,10,14$. Pola pergeseran makna kata tersebut juga berdasarkan persepsi responden akan makna awal kata Taliban. Sehingga dapat disimpulkan bahwa pola peyorasi atau ameliorasi pada pergeseran kata yang belum memiliki makna yang ditetapkan bergantung pada persepsi penutur terhadap makna asal kata.

Dalam analisa siknronik, kata dapat mengalami perluasan makna disebabkan kreatifitas penutur, namun meskipun demikian makna asal kata akan tetap melekat (Ullmann, 1962). Pola pergeseran makna kata "Taliban" berdasarkan persepsi penutur dapat dijabarkan sebagai berikut:

Tabel. 2

Pola pergeseran makna positif dan negatif

\begin{tabular}{cc}
\hline $\begin{array}{c}\text { Makna Awal } \\
\text { Taliban }\end{array}$ & $\begin{array}{c}\text { Makna Baru } \\
\text { Taliban }\end{array}$ \\
\hline+ & + \\
+ & - \\
- & + \\
- & - \\
\hline
\end{tabular}

Diagram. 5

Pola ameliorasi

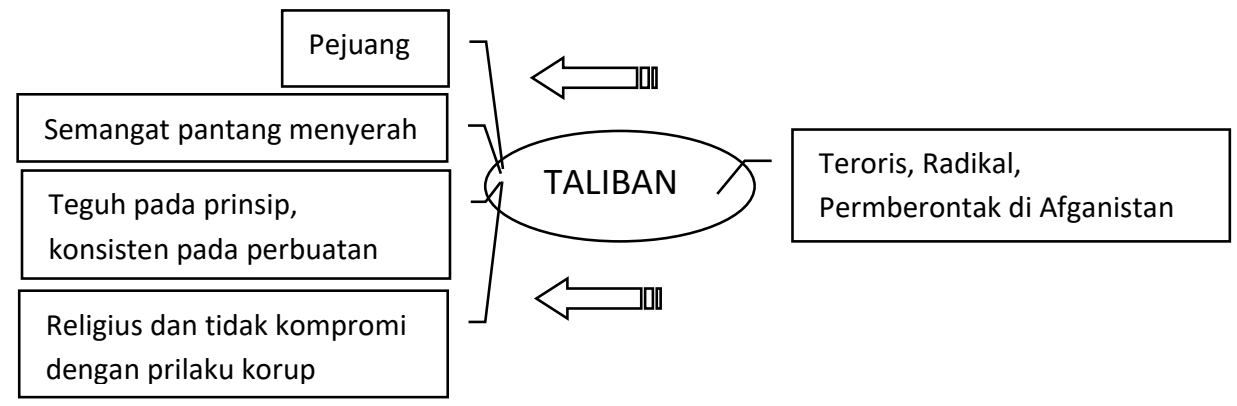

Pada diagram lima, pergeseran makna dari negatif menjadi positif, kata "Taliban" yang awalnya bermakna teroris, radikal dan pemberontak menjadi semangat pantang menyerah, pejuang, tegus pada prinsip dan konsisten pada perbuatan, religius dan tidak kompromi dengan prilaku korup.

Proses pemaknaan kata asing yang digunakan dalam bahasa tertentu, pola perluasan kata ataupun penyempitan merupakan hal yang sering terjadi. Perluasan makna merupakan proses yang dihasilkan dari generalisasi suatu kasus yang terjadi pada kelas masyarakat tertentu, dimana kata tersebut mengalami penambahan makna (Pupier, 2006). 


\section{Diagram 6.}

\section{Pola Peyorasi}

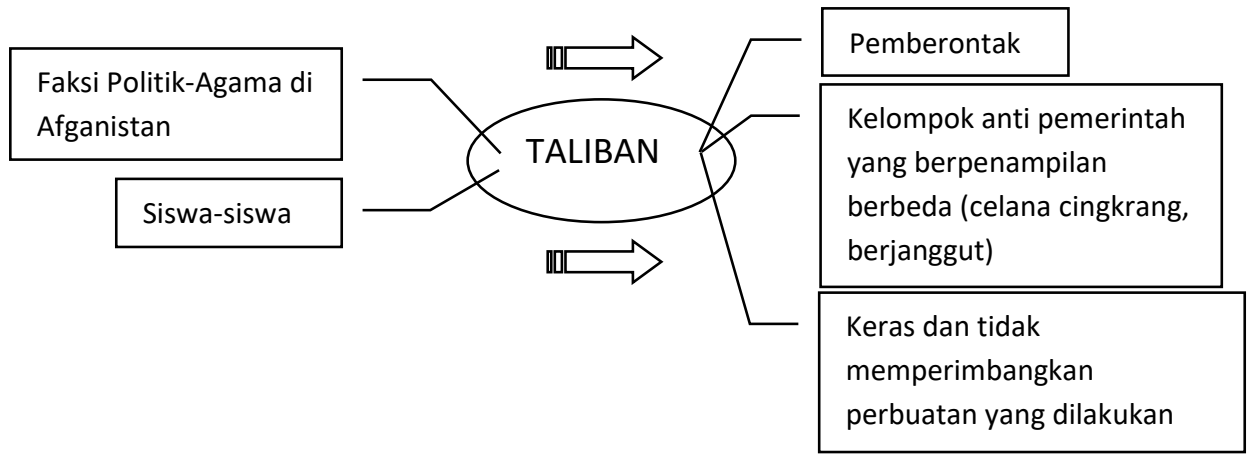

Pada kasus pergeseran makna kata Taliban, kreatifitas dan wawasan penutur berperan terhadap perkembangan makna, hal tersebut dapat diamati pada makna yang dikembangkan oleh resonden yang berbeda-beda. Beberapa respondon bahkan cenderung memberikan makna yang sangat sederhana seperti "pejuang", "pemberontak", dan "murid yang memiliki keinginan belajar". Sementara beberapa responden mengembangkan makna tersebut lebih kreatif berdasarkan konteks dimakan kata tersebut digunakan seperti; "Kelompok yang memanfaatkan nama besar dan Marwah KPK untuk kepentingan pribadi dan kelompoknya", "Semangat militan yang dalam konteks pekerjaan sebagai kiasan untuk orang terlalu bersemangat dalam bekerja" dan beberapa makna lain pada tabel 1.

\section{Konstruksi Makna}

Mengasosiasikan makna Taliban dengan mengambil makna tertentu dari medan makna menunjukkan adanya pola penyempitan makna. Namun yang menjadi unik adanya pemaknaan tertentu yang sangat jauh dari makna asal kata Taliban dalam bahasa Phasto. Hal ini menunjukan adanya kebebasan penutur terhadap kata yang belum ditetapkan maknanya untuk mengembangkan makna dalam konteks situasi dan sosial tertentu.

Proses Meminjam dari sumber asing akan memunculkan pemetaan inovasi antara kata dan konsep dalam suatu sistem linguistik. Dalam proses peminjaman kata asing materi leksikal juga diadaptasi (Bowern \& Evans, 2015). Pada kasus pemaknaan kata asing, proses peminjaman dapat mencakup makna dan simbol atau hanya meminjam simbol saja tanpa makna. Formasi kata asing yang digunakan, juga sangat bervariasi.

Banyak faktor yang mempengaruhi proses konstruksi makna. Makna figuratif bermunculan selama proses perluasan makna hingga akhirnya yang disepakati secara sosial oleh suatu komunitas bila terjadi. Namun pada kasus pergeseran makna Taliban, makna tersebut tetap memiliki makna yang beragam pada komunitas pegawai KPK namun publik diberikan keluasan untuk memberikan makna, sehingga konstruksi makna yang utuh belum benar-benar 
tercapai sampai akhirnya publik dilupakan dengan penggunaan kata "Taliban" seiring berjalan waktu.

Sistem makna terkonstruksi melalui budaya dan pengalaman dan wawasan seseorang. Sifat otonom pada budaya seseorang mempengaruhi bagaimana makna terkonstruksi dan mengalami pergeseran. Dari makna yang baku menuju simbolsimbil figuratif yang dibangun atas dasar pengalaman dan asosiasi kesamaan pada pemahaman makna suatu kata. Keadaan tersebut tercermin pada kata "Taliban" yang mengalami konstruksi makna tertentu dan sangat otonom dibangun oleh masing-masing individu secara bebas, kreatif berdasarkan asosiasi yang dipahami oleh individu-individu.

Makna diakses dan tertanam dalam dan melalui sistem budaya, pemahaman kognitif secara intersubjektif dibagikan oleh kelompok sosial apabila makna tersebut telah mencapai titik kesepakatan (D'Andrade, 1987). Makna kata merupakan konseptualisasi umum dan pemahaman bersama sekelompok individu, namun dalam perjalanannya pemahaman bersama tersebut diawali oleh pemahaman individu. Dimana proses tersebut melewati pola konstruksi yang mungkin beragam.

Pergeseran makna dipengaruhi oleh kreativitas penutur yang berproses terhadap keragaman makna hingga bermuara pada persamaan konseptual bersama. perkembangan makna tersebut tidak dapat diprediksi namun menemukan kesimpulan dalam fenomena singkronik ketika terjadi penggunaan kata secara masal dan terbuka. Konstruksi tersebut memerlukan waktu dan dipengaruhi oleh aspek kognitif penutur dan faktor sosial kultural.

Pada makna kata "Taliban" pola konstruksi diawali dengan simbol yang dikandung dan dipahami oleh tiap individu adalah beragam terhadap kata "Taliban", selanjutnya pergeseran makna harus melewati simbol awal yang dipahami tersebut, sehingga terjadi proses asosiasi, penyesuaiaan budaya dan konteks sosial.

konstruksi individu makna "Taliban" dapat disederhanakan sebagai berikut.

\section{Diagram 7.}

\section{Konstruksi Makna Individu}

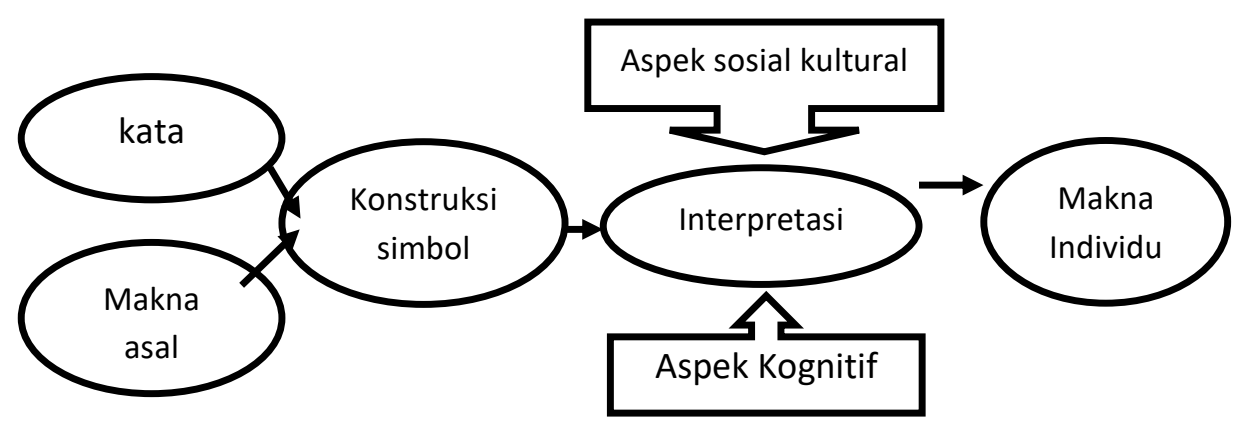

Jurnal Ilmiah Program Studi Pendidikan Bahasa Arab IAIN Palangka Raya Vol. 8, No. 2 /161-176 Al-Ta'rib | p-ISSN 2354-5887 | e-ISSN 2655-5867 
Pada makna kata "Taliban" pola konstruksi diawali dengan simbol yang dikandung dan dipahami oleh tiap individu adalah beragam terhadap kata "Taliban", selanjutnya pergeseran makna harus melewati simbol awal yang dipahami tersebut, sehingga terjadi proses asosiasi, penyesuaiaan budaya dan konteks sosial. Pada perspektif lain, suatu kata terkontruksi dengan mengakomodasi pengetahuan bersama komunitas, kepercayaan dan nilai-nilai budaya. Kontruksi makna baru dapat dipengaruhi oleh makna metafora atau sifat yang berada dalam medan makna awal kata tersebut (Holmes, 2013). Maknamakna baru yang dimiliki oleh individu-individu dalam suatu komunitas akan berperoses menuju pemahaman bersama untuk membentuk makna sosial dimana aspek komunikasi dan interaksi sosial akan sangat berpengaruh dalam suksesnya konstruksi makna.

Makna-makna personal akan membentuk beberapa makna sosial dalam ruang lingkup lebih kecil untuk selanjutnya bertransformasi menjadi makna sosial dalam ruang yang lebih besar, hal tersebut terjadi ketika terdapat persamaan makna yang disepakati bersama secara alamiah. Apabila terjadi hambatan yang berakibat pada terhentinya proses konseptualisasi umum dan pemahaman bersama, sebuah kata hanya akan berhenti sebatas makna individu atau makna sosial kecil saja.

Konstruksi makna dalam Komunitas tertentu yang berbeda dengan makna yang dipahami oleh masyarakat dapat menimbulkan konflik sosial. Kata yang dipahami dengan makna positif dalam komunitas tetapi dimaknai berbeda oleh masyarakat bahasa atau bahkan tidak tanpa makna, dapat dengan mudah disalahgunakan ketika suatu kelompok memanfaatkan kata dengan memberikan makna negatif pada kata dan menyebarkannya dilingkungan yang lebih luas.

\section{Kesimpulan}

Pada makna kata "Taliban", medan semantik yang digunakan berbentuk nomina dan adjektiva dengan makna beragam. Nomina memiliki acuan individu disatu sisi dan sosial pada sisi lain. Pola konstruksi makna diawali dengan asosiasi simbol yang dikandung dan dipahami oleh tiap individu, yang berlanjut dengan interpretasi makna dalam bingkai wawasan individu, proses asosiasi, penyesuaiaan budaya dan konteks sosial. Makna individu yang terkonstruksi dalam suatu komunitas mungkin berlanjut pada pemahaman bersama dan konseptualisasi makna umum apabila faktor-faktor sosial-situasional mendukung terjadinya konstruksi makna utuh. Namun proses tersebut dapat terhenti dan bermakna mengambang serta dipahami oleh publik secara liar.

Tipe peyorasi dan ameliorasi merupakan pola perubahan yang paling nampak. namun, pemaknaan positif-positif juga merupakan pola berbeda yang ditemukan dalam pergeseran makna Taliban di KPK. Perkembangan pemaknaan kata secara liar dan tanpa pengawasan dalam kasus tertentu dapat menjadi alat untuk memunculkan konflik. Seperti menggunakan kata yang mengandung kemungkinan untuk mengalami peyorasi ataupun ameliorasi, kata tersebut dapat digunakan sebagai alat pemicu konflik disebabkan adanya kemungkinan 
pemaknaan yang berbeda. Pada kata "Taliban" konsepsi umum dan pemahaman bersama diragukan dapat terkonstruksi secara luas. Pemaknaan bebas-otonom pada kata "Taliban" menjadi pola yang berlangsung baik pada komunitas KPK ataupun pada masyarakat umum. Tanpa intervensi perbedaan makna berpotensi mematik konflik.

\section{Referensi}

Aitchison, J. (2003). Linguistics. Hodder \& Stoughton, Ltd.

Anuradha, M. V., Srinivas, E. S., Singhal, M., \& Ramnarayan, S. (2014). To Work or Not to Work: Construction of Meaning of Work and Making Work Choices: Vikalpa. https://doi.org/10.1177/0256090920140203

Baalbaki, D. R. (1998). Al-Mawrid A Modern English-Arabic Dictionary (4th edition). Dar El-ilm Lilmalayin.

Bloomfield, L. (1933). Language. Compton Printing Ltd.

Bowern, C., \& Evans, B. (2015). The Routledge Handbook of Historical Linguistics. Routledge.

Brinton, L. J. (n.d.). The Structure of Modern English. In Z.94. John Benjamins Publishing Company. Retrieved December 3, 2020, from https://benjamins.com/catalog/z.94

Chaer, A. (1990). Pengantar semantik bahasa Indonesia. Rineka Cipta. http://books.google.com/books?id=snotAAAAMAAJ

Crystal, D. (1997). The Cambridge Encyclopedia of the English Language. Cambridge University Press.

D'Andrade, R. (1987). "A Folk Model of the Mind." Pp. 112-50 in Cultural Models in Language and Thought, edited by Dorothy Holland and Naomi Quinn. Cambridge University Press.

Hamilton, W. L., Leskovec, J., \& Jurafsky, D. (2016). Cultural Shift or Linguistic Drift? Comparing Two Computational Measures of Semantic Change. Proceedings of the 2016 Conference on Empirical Methods in Natural Processing, 2116-2121. https://doi.org/10.18653/v1/D16-1229

Holmes, J. (2013). An introduction to sociolinguistics (4. ed). Routledge.

Jasim, A. (2007). Mustalahat ad-Dilalah Arabiyah. Darul Kutub Ilmiah.

Kampung Gusdurian. (n.d.). Retrieved December 3, 2020, from https://gusdurian.net/id/article/headline/Taliban-Oh-TalibanKamu\%20Ngapain-Sih-di-KPK/

Kane, A. E. (2016). Theorizing Meaning Construction in Social Movements: Symbolic Structures and Interpretation during the Irish Land War, 18791882*: Sociological

Theory. https://journals.sagepub.com/doi/10.1111/0735-2751.00034

Leech, G. N. (1981). Semantics: The study of Meaning. Penguin Books. 
Naim, A. (1982). Kamus Farisiyah. Dar Kutb Banani.

News, T. (2017, December 23). Denny Siregar: Irjen Firli, Momok bagi Taliban di KPK. TAGAR. https://www.tagar.id/denny-siregar-irjen-firli-momok-bagitaliban-di-kpk

Nida, E. A. (1975). Componential Analysis of Meaning: An Introduction to Semantic Structures. Mouton.

Pupier, P. (2006). Laurence R. Horn et Gregory Ward, eds. The handbook of pragmatics. Oxford: Blackwell, 2004. Pp. xix + 842. 157,95\$US (relié). Canadian Journal of Linguistics/Revue Canadienne de Linguistique, 51(1), 85-94. https://doi.org/10.1017/S0008413100003947

Rahma, F. A. (2018). Pergeseran Makna: Analisis Peyorasi Dan Ameliorasi Dalam Konteks Kalimat. Hasta Wiyata, 1(2), 1-11. https://doi.org/10.21776/ub.hastawiyata.2018.001.02.01

Raverty, H. G. (2001). A dictionary of the Pukhto, Pushto, or language of the Afghans ... Sang-e-Meel Publications. https://catalog.hathitrust.org/Record/003840475

Sempana, R., Cahyono, B. E. H., \& Winarsih, E. (2017). Analisis Perubahan Makna Pada Bahasa Yang Digunakan Oleh Komentator Sepak Bola Piala Presiden 2017 Kajian Semantik. Widyabastra: Jurnal Ilmiah Pembelajaran Bahasa dan Sastra Indonesia, 5(2), 78-86.

Ullmann, S. (1962). Semantics: An introduction to the science of meaning.

Wijana, I. D. P., \& Rohmadi, M. (2008). Semantik: Teori dan analisis (Cet. 1). Yuma Pustaka.

Wiwitan, T., \& Yulianita, N. (2018). Konstruksi Makna Marketing Public Relations di Perguruan Tinggi Islam Swasta. INA-Rxiv. https://doi.org/10.31227/osf.io/5nkhp

\section{Copyright Notice}

Authors retain copyright and grant the journal right of first publication with the work simultaneously licensed under a Creative Commons Attribution 4.0 International License that allows others to share the work with an acknowledgement of the work's authorship and initial publication in this journal.

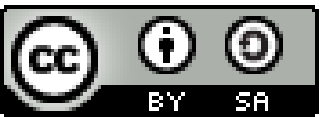




\section{HALAMAN INI SENGAJA DIKOSONGKAN}

